\title{
HEALTH CARE IN THE BIBLE AND THE TALMUD
}

\section{by Lilian M Medlen}

\author{
Research Assistant, Deptartment of Nursing Science \\ University of South Africa
}

\begin{abstract}
"Honour the physician according to thy need of him with the honours due to him; for verily the Lord hath created him; for from the most High cometh healing, ...."

(Ecclesiastes $38: 1,15$ )
\end{abstract}

\section{OPSOMMING}

Daar is 'n rykdom van kosbare materiaal ten opsigte van mediese kennis in die Bybel en die Talmud te vind. Melding van 'n groot aantal siektes word gemaak, asook die diagnosering, behandeling en voorkoms daarvan. Dikwels word melding ook gemaak van onderwerpe soos etiek vir die geneesheer, anatomie enfisiologie, forensiese geneeskunde, geestelike ongesteldhede en veral higiëniese maatreëls. Dit is nie verniet dat Moses die "Vader van Voorkomende Geneeskunde" genoem word nie.

Daar bestaan 613 Bybelse voorskrifte en beperkinge waarvan 213 gesondheidsreëls is.

Die Antieke Hebreeus het die beginsels van voorkomende geneeskunde via 'n godsdienstige roete na die Weste oorgedra.

667 he thought patterns of occidental civilization have been basically influenced by the mentalities of two peoples: the ancient Greeks, with their lucid reasoning and logical approach to scientific problems, and the People of the Book, with their intuitive ethical teachings, their timeless moral laws, and, last but by no means least, their ethically based health rules." (Rosner, p.3).

No one, not even the most sophisticated modern-day health-care professional, can read Leviticus without amazement. Moses has justifiably been called the "Founder of Preventive Medicine". (Rosner, p.3). Karl Sudhoff, the great German historian of medicine states "Two of the greatest hygienic thoughts of mankind owe their origin to Semitism ... the weekly day of rest and the direct prophylaxis of disease"'. (Rosner, p.3).

There are 613 Biblical commandments and prohibitions of which no less than 213 are health rules which were enforced by strictly observed ceremonial rites.

"The whole concept of the isolation of disease became the property of the West by the religious route'. (Rosner, p.3). Medicine and religion, among the ancient Hebrews, were inextricably intertwined, as they were among all ancient peoples. Hygienic laws were enforced as religious laws, and the breaking of one of these laws with the possible illness which resulted, was interpreted as Divine punishment. Nevertheless, it would appear that although the supernatural played a major role in their thinking on the causation of disease, the awareness of the transmission of disease was there.

Although they resembled other contemporary cultures in the amalgamation of medicine and religion, medical practice amongst the Jews nevertheless differed in certain vital aspects. Incantations and exorcisms, therapeutic measures which were widely practised in the ancient world (and still are to-day), were frowned upon by the Jewish religious leaders, as were other magical and superstitious practices. The enforcement of the sanitary laws was entrusted to the priests, but not the actual treatment of the sick. There were physicians - ('Is there no balm in Gilead? Is there no physician there?' - Jer. $8: 22$ ), pharmacists ('and thou shalt make it a perfume, a confection after the art of the apothecaries' Neh. 3:8), male nurses ("tiflim" in the Book of Job), and midwives ('and the king of Egypt spoke to the Hebrew midwives ... - Exod. 1:15).

However in the monotheistic concept of ancient Israel there were no "healers". Only God could "heal" sickness. Those physicians who called themselves "healers" (rofé in Hebrew) were generally foreigners and are spoken of in a derogatory fashion (Jer. 8:22, Hosea 5:13, Job 13:4). There was also a distinction made between physicians, surgeons and blood-letters the latter being considered of a lower social order.

The geographic setting of the Talmudic era covered not only Israel but also the adjacent countries. After the fall of the Second Temple (70 AD) and the loss of Jewish statehood, the sages feared that the oral tradition or law would be lost or forgotten. (This oral tradition was the interpretations of Biblical law which had accumulated over the centuries). Accordingly the oral tradition was committed to writing about $200 \mathrm{AD}$ and is 
called the Mishnah. Later generations, in Palestine and Mesopotamia, added commentaries and supplements which together with the Mishnah is called the Talmud. The Talmudic era covered the period from 200 AD 600 AD. (The Talmud, being a compendium of commentaries and elaborations on Biblical teachings, also includes commentaries on medical problems, and reflects the influence of Greek, Babylonian and Persian medicine).

Neither the Bible nor the Talmud were intended to be medical reference texts yet they contain a specialised Hebrew nomenclature for certain diseases and parts of the human anatomy. (See Preuss, Rosner et al).

A noted Biblical scholar, Jesus Ben Sira (Ca. 150 B C E) wrote at some length on the importance of medicine and the role of the physician. It was primarily due to Ben Sira's influence that the physician through the ages, was held in such high esteem among the Jews, right up to the present time. "The rabbi-physician chose the practice of medicine not only as a means of livelihood but as a favourite occupation because of the opportunity it afforded to devote one's life to good deeds and to become the instrument of Providence to bring relief". (Friedenwald, p.17).

A noted Talmudist who was also an outstanding physician was Mar Samuel. He had considerable knowledge of pharmacology and anatomy.

The Jewish sect, the Essenes, were active not only in religious and moral questions, but also in medical problems. They lived in small monastic groups devoting themselves to handcrafts and the healing of the sick. The name Essene is derived from the Aramaic 'assia' meaning 'helpers', i e physicians and therapists. Their therapeutic objectives were to bring the patient's soul "nearer to perfection and thus to God". Many of their teachings were adopted by the early Christians.

"There were many other Talmudic scholars who commented on health problems, and that they possessed a hygienic conscience is evident from the Public Health regulations scattered through the Talmud. The chief contribution of Talmudic medicine, like that of Biblical medicine, was not so much in therapeutic measures as in preventive medicine expressed in health rules based on religious and ethical principles." (Rosner, p.19).

It is surprising therefore that Biblical and Talmudic medicine had no influence on mediaeval medicine - not even on the great Jewish physicians, such as Maimonides, who were thoroughly conversant with Talmudic literature. Mediaeval medicine was totally under the influence of Galen ( $\pm 150 \mathrm{~A} \mathrm{D})$ who was accepted as infallible on all things medical, and the health rules in the Bible and the Talmud were dismissed as being purely religious laws. "The historians of medicine are unanimous in their view that the science of the healing art made no progress for many centuries after the time of Galen". (Rosner, p.20).

\section{PREVENTIVE HEALTH IN THE BIBLE AND THE TALMUD}

The main emphasis is not on therapy but on preventive medicine and physical and mental hygiene, as applied to the individual, the family, the people, and socie- ty in general. It is not possible here to enumerate all the public health laws appearing in the Bible and Talmud, suffice it to say there were rules about eating, drinking, exercise, clothing, washing and bathing, family relations, the building of houses, the preparation of food, foods to be avoided, the laying out of the dead, the disinfection of dwellings, the care of the sick and isolation of contagious disease.

Some examples of these laws can be given. When a watercourse was constructed for the washing of clothes, it was illegal for it to be constructed near a party wall, and an embankment had to be constructed to prevent contaminated water percolating into neighbouring property; threshing-barns, tanneries and carcasses were not allowed within the city walls; shoes were to be worn as the soil was recognized to be a focus of infection: there were ritual laws of purity and impurity of the human body, utensils and clothing; there were rules of defilement relating to the Temple, priests, cadavers, lepers and the purification process; there were dietary prohibitions against the eating of blood and fat and certain meats, particularly pork; there were social hygienic laws applying to sex relations and family life; there were rules about the diagnosis of infectious disease (which was done by a priest, Lev. 14:35-45) and the prevention of epidemics; the clothing and gear of soldiers returning from war had to be disinfected and metal objects passed through fire. Moreover, the clothing and arms could not be used for seven days after disinfection (Num. 31:16-24, see also Deut. 23:12-14 and Lev.). Biblical medicine shows an awareness of the fact that diseases can be communicated through utensils or a third person, and that overcrowding and malnutrition were contributory causes of epidemic disease.

The warnings in Leviticus 18:3 "After the doings of the land of Egypt . . . shall ye not do" refers not only to human relations, but also to health regulations, which the nations surrounding the Children of Israel, did not practise.

"The hygienic spirit is expressed in the dictum that 99 per cent of disease is due to the transgression of the laws of health". (Snowman, p.27).

\section{SPECIFIC DISEASES}

A great many diseases are mentioned in the Bible and the Talmud, as well as their diagnosis, cure and prevention. Some example of these diseases are epilepsy, tuberculosis, leprosy, dysenteric disorders, gout, rabies, scurvy, haemophilia, helminthic diseases, puerperal fever, and various unidentifiable fevers.

Space prohibits a more detailed description of all the diseases to be found in these works. The few diseases mentioned below will give an indication of the scope of this subject.

\section{Leprosy (Hebrew zara'at)}

According to Preuss and other Semitic philologists the term "zara'at" could mean not only leprosy, but also psoriasis and other skin diseases. The 13th book of Leviticus deals with "zara'at" and in 
many other sections of the Bible and the Talmud, reference is made to various skin lesions, scabs, boils, scars and eczema. Abnormal shapes and disfigurements of the nose are described, and surgeons in Talmudic times are known to have amputated limbs for leprosy.

There are several well-known figures in the Bible who suffered from leprosy (zara'at), amongst whom were Job, Hezekiah and Miriam, the sister of Moses. Mention is also made of lepers in the New Testament. The illness of Job and Hezekiah could have been leprosy, according to Preuss, but it could also have been elephantiasis, syphilis, diptheria or variola.

There were houses set apart for lepers. (See 2 Kings 15:5, 2 Chron. 26:21).

\section{Gout ("podagra")}

In 1 Kings $15: 23$ and 2 Chron. 16:12, there is a description of the disease of the feet suffered by King Asa of Judah. The Babylonian Talmud, commenting on King Asa's illness calls it "podagra" and likens it to "a needle in the raw flesh".

\section{Epilepsy}

Epilepsy is mentioned in the Bible as "the sayings of him who ... sees the vision of the Almighty", and "fallen down, yet with opened eyes" (Num. 24:4). The pagan prophet Balaam, whose fit is described in the passage from Numbers, is thought to have been epileptic. Also the falling of Saul the whole day and the whole night during his search for Samuel and David (1 Samuel 19:24) is thought to have been epileptic seizures. In the New Testament there are descirptions of epileptic seizures in Luke 9:39, Mark 9:18, and Matthew 27:15. Not a few of the ancient prophets and soothsayers are now thought to have been epileptics.

The causes of epilepsy were just as puzzling to the ancients as they are to us to-day, and they came up with many improbable answers. However, they recognized the hereditary aspects of the condition and the mental sequelae of a post-epileptic state. Charms and exorcisms played a part in popular treatment, although these were condemned by the rabbis.

\section{Female disorders Venereal disease}

The adultery committed by the Children of Israel with the daughters of Moab (Num. 25) resulted in an epidemic or infectious disease which was probably syphilis.

There were Jewish ritual laws dealing with venereal disease and its causes and mode of transmission. (See Mishnah quotation Mikwaoth 8, 2-4 for diagnosis of gonorrhoea in males).

\section{Gynaecology and obstetrics}

The menstrual cycle and disorders thereof were well-known. In Leviticus 15:25 the distinction is drawn between menstrual and non-menstrual haemorrhage, though no description of female discharges is made.
A primitive speculum in the form of a hollow leaden tube with a wad of cotton at the end, was used in Talmudic times for the gynaecological examination of a woman with menorrhagia. This description $( \pm 259 \mathrm{~A} \mathrm{D})$ is the earliest mention of the use of such an instrument.

Mar Samuel (165 - 257 A D) describes in the Talmud the development of the foetus and declares that before 40 days it is "mere fluid" but assumes form and shape from that time on. It is interesting to note that abortions were allowed before the fortieth day, but not after that time.

Numerous methods of contraception are discussed in the Talmud and plant remedies are discussed as abortifacients. Descriptions are given too of moles, monster births, false pregnancy, difficult labour and embryotomy. The Talmudists had a remarkable knowledge of anatomy and physiology and apart from foetal development they correctly described the female anatomy and the correct number of pulmonary lobes which Galen did not.

However, they were also at fault in some of their deductions such as that the amenorrhoea of pregnancy "was caused by the gradual conversion of blood into milk." (Snowman, p.6). Many of their vegetable preparations for the cure of uterine haemorrhage were accompanied by the exhortation "Arise, freed from thy haemorrhage" - therapeutic suggestion.

\section{Ethics and the Jewish physician}

The Jewish physician was expected to treat his patients in a sympathetic and humane manner. The duty to treat the injured is expressed in Exodus $21: 18,19$, and duties towards one's fellowmen in Leviticus 19:11-16. To care for one's health was regarded as a religious duty. According to the Sanhedrin Jews were forbidden to live in a city without a physician.

It was regarded as right and proper that the physician should receive payment for his services but it was generally agreed that it was not up to men to judge physicians who failed or made mistakes in the treatment of patients, but the prerogative of God alone. Each physician had to have a license from a court of justice to practise, and in Babylonia Jewish physicians were organised in a guild with a palm or peach branch as emblem.

The ethical standards set up for the Jewish physician were very high. Less could not have been expected of those who followed the profession of Him who said: "I am the Lord that healeth thee." (Exod. 15:26).

\section{Surgery}

A distinction was made between physicians and surgeons. Surgeons wore special surgical aprons, and needles and instruments for venesections are described. Metal instruments were avoided if possible as they were thought to cause inflammation, iron particularly was under suspicion. There is a description of a procedure to follow with an imperforate anus where a grain of barley is advised for making the incision. 
Venesection, the sewing-up of wounds, trephinations, amputations, splenectomies, catheterizations of the throat and even plastic surgery are described in the Talmud. There were also "operating rooms" (batei shayish) with marble-panelled walls.

The various ways in which wounds heal was noted and it was generally recognised that deep wounds should heal from the bottom up. It was advised not to touch wounds because "hands cause inflammation". Cress steeped in vinegar was a favoured haemostatic. Abscesses were opened and scraped, but this was preceded by charms or superstitious gestures.

Gangrenous or leprous limbs which had been amputated were buried in a separate section of the cemetry, and there was a specific ritual of washing and the burning of clothes to be followed by both the patient and the surgeon after such an operation.

There is also frequent mention made of the use of anaesthetics, or sleeping draughts, and disinfectants which were generally vegetable concoctions.

\section{CONCLUSION}

In 1911 Julius Preuss, who was both a physician and expert Semitic philologist, published his "BiblischTalmudische Medizin" which is the authorative work on the subject.
The various selections mentioned here are only a small portion of the wealth of health-care to be gleaned from Biblical and Talmudic literature. In studying this subject one can use the chronological approach or look for specific topics, subjects or disease entities.

The religious laws of the Jews emphasised the rules which a healthy person should follow not to become ill. Preventive health care rather than therapeutic care is the major theme in Biblical and Talmudic health teaching. Unfortunately these teachings were ignored in the Middle Ages because both Jewish and Christian scholars regarded these health care principles as purely religious codes. In fact some commentators (Tosafot) criticized the ancient health theories as being outdated and even dangerous, because in their opinion conditions and ways of living had changed.

This ancient health-care lore is of particular interest to modern healthcare professionals today where the emphasis in community health is on preventive health care.

The study of ancient health-care brings us to the realisation that there is nothing new under the sun. 